\title{
Efficacy of Olive Leaves Extract on the Survival Pattern of Salmonella Typhimurium and Staphylococcus Aureus in Minced Meat
}

\author{
Taghreed A. Hafez ${ }^{*}$ and Abdelrahman, H. A. ${ }^{* *}$
}

Department of Food Hygiene, Animal Health Institute, Port-Said Regional Laboratory, Egypt. ",Department of Food Hygiene and Control, Veterinary Medicine Sues Canal University, Ismailia, Egypt"

\section{Abstract}

The application of plant extract as bio-preservatives, for meat products, was recommended by many researchers; therefore an aqueous extract of olive leaves (Olea europaea L.) was examined for its effect on the survival pattern of Salmonella typhimurium and Staphylococcus aureus which were experimentally inoculated in minced meat with an initial load of approximately $10^{6} \mathrm{cfu} / \mathrm{g}$. All samples of meat were stored at $7 \pm$ $1{ }^{\circ} \mathrm{C}$ for 24 hours. The results indicated that olive leaves extract showed a significant effect on the survival pattern of Staphylococcus aureus and a lower effect against Salmonella typhimurium. Sensory examination revealed that the addition of $1 \%$ OLE to minced meat had significantly better overall acceptability. From this study we can conclude that olive leaves extract contain compounds that have significant antimicrobial properties, which can be applied to use in the meat industry.

Keywords: Olive leaves; Phenolic compounds; Antibacterial activity; Sensory quality. Salmonella typhimurium, Staphylococcus aureus

\section{Introduction}

Safety of food is an important priority as 1 in 6 Americans (48 million people) get sick, 128,000 are hospitalized and 3,000 die of food borne diseases each year according to (CDC, 2011) Antimicrobials are used in food to control natural spoilage processes, and to prevent/control growth of micro-organisms, including pathogenic micro- organisms. Due to the increase concerns on chemical preservatives among consumer, natural antimicrobials are receiving a good deal of attention. Although chemical preservatives are approved for human consumption by government agencies but many of these chemical preservatives are threaten our health. So, the food researchers have given more attention towards the useful use of natural products as antimicrobials. (Mathew et al, 2007; Abou-taleb and Kawai, 
2008; Fisher and Phillips, 2008 and Sofos, 2008).

Natural antimicrobials are promising solve for the increasing concerns antibiotic resistance and could yield better results than synthetic antimicrobials (Ngwoke, 2011).

Olive Leaf Extract (OLE) has been used clinically for many years and have promising therapeutic action against many common and chronic conditions. (Healthy Christian Living, 2014)

Antimicrobial and antioxidant activity of olive Leaf Extract (OLE) is directly related with its polyphenols namely oleuropein, tyrosol, hydroxytyrosol, rutin, verbacoside, apigenin- 7-glucoside and luteolin-7-glucoside (Korukluoglu et al, 2010). There are some studies revealing olive leaf extract inhibits many gram-negative and -positive bacteria, and can inhibit the sporulation of Bacillus cereus and growth of Escherichia coli, Klebsiella pneumoniae, Salmonella typhi, Vibrio parahaemolyticus and Staphylococcus aureus, that all known as food pathogens (Markin et al, 2003 and Pereira et al, 2007). Unlike synthetic antibiotics, it destroys only the bad bacteria and protects the good. Olive leaf extract offers the benefits of being a broadspectrum antimicrobial compound while at the same time exhibiting no harmful effects on beneficial microbes. Because it will not induce any side effects which could be associated with antibiotics, and will not lead to secondary infections related to a preponderance of harmful bacteria (Hansen et al, 2013). The application of plant extract as bio-preservatives, for meat products, was recommended by many researchers (Erdohan, 2011). Many plant extracts were evaluated to decontaminate and maintain the quality of meat steaks (Tayel et al, 2012) and ground beef (Tayel and El-Tras, 2012). The present study was designed to evaluate the effect of olive leaves extract on the survival pattern of Salmonella typhimurium and Staphylococcus aureus in minced meat.

\section{Materials and methods Preparation of OLE}

Olive leaves were collected from Olea europaea L. trees. They were collected in winter season and dried in air. The extract was prepared according to (Devatkal et al, 2012).

\section{Inoculation of meat}

Reference Staphylococcus aureus and Salmonella typhimurium strains were obtained from The Animal Health Research Institute- Food Hygiene Department, Agriculture Center Research, and Egypt.

Antibacterial activity of OLE Meat sample was obtained from the local supermarket at Port- Said City and transferred directly to the laboratory under complete aseptic conditions without delay. The meat samples were cut into pieces, and minced using meat grinder. Minced 
meat

$(1 \mathrm{~kg})$

examined bacteriologically for the presence of Staphylococcus aureus and Salmonella typhimurium according to (FDA, 2001) and (FDA, 2007) respectively. The minced meat sample was divided into 3 equal samples each weight nearly of $330 \mathrm{~g}$, the first portion was inoculated by the reference strain of Staphylococcus aureus and the second with Salmonella typhimurium, and the third portion was used for the sensory evaluation. Preliminary work was conducted to determine the concentration of inoculums of the reference strain volume which are needed to yield $10^{6} \mathrm{cfu} / \mathrm{g}$ in minced meat according to QSOP 18, (2005).

Each inoculated meat samples was subdivided into 4 portions and mixed with $0 \%, 1 \%, 2 \%$ and $3 \%$ OLE (w/v) and stored at $7^{\circ} \mathrm{C}$ and examined after 2 hours and 24 hours for Staphylococcus aureus and Salmonella typhimurium according to (FDA, 2001) and (FDA, 2007) respectively.

\section{Sensory evaluation}

The Sensory characteristics of minced meat samples were evaluated in the $3^{\text {rd }}$ portion which was subdivided into 4 portions and each one was mixed with the corresponding dilutions $0 \%, 1 \%$, $2 \%$ and $3 \%$ OLE (w/v). These concentrations were chosen to be the same as the concentrations that were used in the microbiological examination. The sensory evaluation was conducted by the 5 points hedonic scale: 1 , very poor; 2, poor; 3, common; 4, good; 5, very good (Szczesniak, 1987).

\section{Statistical analysis}

All measurements were repeated three times. The results are expressed as mean values and standard deviations. The data were statistically analyzed by ANOVA and Duncan's multiple range tests. Statistical significance was accepted at a level of $\mathrm{P}<0.05 \quad(\boldsymbol{S} \boldsymbol{A S}$ Institute, 1988).

\section{Results}

Table 1. Effect of olive leaves extract on populations of Staphylococcus aureus and Salmonella typhimurium

\begin{tabular}{|c|c|c|c|c|}
\hline \multirow{2}{*}{$\begin{array}{c}\text { OLE } \\
\%\end{array}$} & \multicolumn{2}{|c|}{ Staphylococcus aureus } & \multicolumn{2}{c|}{ Salmonella typhimurium } \\
\cline { 2 - 5 } & 2 hours & 24 hours & 2 hours & 24 hours \\
\hline \multirow{2}{*}{$0 \%$} & $7.4 \times 10^{6}$ & $8.2 \times 10^{7}$ & $6.5 \times 10^{6}$ & $7.1 \times 10^{7}$ \\
& \pm 0.010 & \pm 0.150 & \pm 0.076 & \pm 0.100 \\
\hline \multirow{2}{*}{$1 \%$} & $1.5 \times 10^{6}$ & $4.1 \times 10^{5}$ & $4.8 \times 10^{6}$ & $3.1 \times 10^{6}$ \\
& \pm 0.07 & \pm 0.150 & \pm 0.100 & \pm 0.100 \\
\hline \multirow{2}{*}{$2 \%$} & $7.4 \times 10^{5}$ & $9.8 \times 10^{4}$ & $2.9 \times 10^{6}$ & $9.8 \times 10^{5}$ \\
& \pm 0.100 & \pm 0.170 & \pm 0.115 & \pm 0.057 \\
\hline \multirow{2}{*}{$3 \%$} & $1.2 \times 10^{5}$ & $3.3 \times$ & $1.2 \times$ & $5.7 \times$ \\
& \pm 0.057 & $10^{4} \pm 0.100$ & $10^{6} \pm 0.100$ & $10^{5} \pm 0.07$ \\
\hline
\end{tabular}


Table 2. Effect of different concentration of olive leaves extract on sensory attributes

\begin{tabular}{|l|l|l|l|}
\hline OLE \% & Flavour & Colour & General acceptance \\
\hline $0 \%$ & $4.40 \pm 0.57^{\mathrm{a}}$ & $3.00 \pm 0.00^{\mathrm{a}}$ & $4.66 \pm 0.57^{\mathrm{a}}$ \\
\hline $1 \%$ & $4.00 \pm 0.33^{\mathrm{b}}$ & $3.00 \pm 0.66^{\mathrm{a}}$ & $4.33 \pm 0.33^{\mathrm{a}}$ \\
\hline $2 \%$ & $3.60 \pm 0.57^{\mathrm{c}}$ & $2.53 \pm 0.33^{\mathrm{b}}$ & $3.00 \pm 0.00^{\mathrm{b}}$ \\
\hline $3 \%$ & $3.00 \pm 0.57^{\mathrm{d}}$ & $2.00 \pm 0.33^{\mathrm{c}}$ & $2.33 \pm 0.33^{\mathrm{c}}$ \\
\hline
\end{tabular}

Means bearing similar letters within each column are not differ significantly $(p<0.01)$ otherwise, they differ significantly $(p<0.01)$

\section{Discussion}

From the results given in (Table 1) we observed that the population of Staphylococcus aureus was reduced by $2 \log \mathrm{cfu} / \mathrm{g}$ after 24 hours of storage at $7^{\circ} \mathrm{C}$ with $1 \%$ of OLE concentration, with $2 \%$ concentration the reduction in Staphylococcus aureus was I $\log$ and $3 \log$ after 2 hours and 24 hours respectively. This means that the reduction was affected by the concentration \% of OLE and the time of storage. The findings observed with Salmonella typhimurium were, after 24 hours of storage the reduction was 1,2 and 2 $\log$ reductions with $1 \%, 2 \%$ and $3 \%$ OLE concentration respectively.

The current results indicating that, the count of Staphylococcus aureus and Salmonella typhimurium were decreased while OLE concentration and time of storage increased (Table 1). These findings were paralleled with the findings of Tayel and ElTras, (2012) and Ahmed et al (2014). In vitro studies performed by (Tranter et al, 1993; Tassou and Nychas ,1994; Tassou, 1995; Markin, 2003; Pereira et al,
2007; Markin, 2008; Sudjana, et al, 2009 and Aliabadi et al, 2013) they recoded that lower concentrations of OLE were sufficient to kill $S$. aureus and most pathogenic bacteria. The antimicrobial effect could be also influenced by the original source, time of harvesting, and stage of development. In food applications, these natural antimicrobial compounds could be influenced by intrinsic factors such as composition (e.g., proteins, fat) as well as extrinsic factors (temperature, oxygen limitation) of the food affect the behavior of bacteria in food ecosystems and may act synergistically with preservatives such as antimicrobial agents. Indeed, food components, such as proteins and fat, are known to bind and/or solubilized Phenolic compounds, reducing their availability for antimicrobial activity. Furthermore, it has been reported by many authors that antimicrobial activity of spice is lower in food systems than in microbiological

media (Korukluoglu, 2010 and Saaed et al, 2013). In Studies performed by 
(Aytul et al, 2010 and Gök and Bor, 2012) they discussed that using of 2 and $3 \%$ OLE had the beneficial effect in controlling the microbial load of beef cubes and meatball during storage at $4^{\circ} \mathrm{C}$. The strong antibacterial effect of olive leaves are due to the phenolic compounds including: caffeic acid, verbascoside, oleuropein, luteolin 7Oglucoside, rutin, apigenin 7-Oglucoside and luteolin 4'-Oglucoside (Pereira et al, 2007; Aytul, 2010 and Tahir and Khan, 2012).

In the present study we observed that Salmonella typhimurium as a Gram-negative bacterium is more resistant to the antibacterial effect of olive leaves extract than Staphylococcus aureus (Grampositive) bacteria (Table 1), this agreed with Srinivasan et al (2001) who stated that in general, plant extracts have much greater inhibition effect against Grampositive than Gram-negative bacteria. It may be due to the external lipopolysaccharide wall that surrounds the peptidoglycan cell wall of the former Kuete et al (2007) and Lee and Lee (2010).

\section{Sensory analysis}

Result of analysis of variance revealed that adding of $1 \%$ OLE to minced meat had significantly better overall acceptability compared to untreated or other treated groups (Table 2). The same findings were observed by (Hayes et al, 2009, Hayes et al, 2011;
Tayel and El-Tras, 2012 and Baker, 2014).

\section{Conclusion}

From this study we can conclude that the addition of $1 \%$ OLE lead to reduce the Staphylococcus aureus and Salmonella typhimurium count after 24 hours of storage at $7^{\circ} \mathrm{C}$ and by 2 and $1 \log$ cycle respectively in examined sample of minced meat .Thus the aqueous extracts of olive leaves could be considered as a suitable antibacterial agent with overall sensory acceptability at concentration of $1 \%$ against the tested organisms which are considered the most prevalent food pathogens responsible for meat borne illness.

\section{References}

Ahmed, A. M., Rabii, N. S., Garbaj, A. M. and Aboulghait, S. K. (2014):

Antibacterial effect of olive (Olea europaea L.) leaves extract in raw peeled undeveined shrimp (Penaeus semisulcatus). International Journal of Veterinary Science Medicine 2(1):53-56.

Abou-taleb, M., and Kawai, Y. (2008): Shelf life of semi fried tuna slices coated with essential oil compounds after treatment with anodic electrolyzed $\mathrm{NaCl}$ solution. Journal of Food Protection 71(4): 770-774.

Aliabadi, M. A., Darsanaki, R. K., Rokhi, M. L., Nourbakhsh, M. and Raeisi, G. (2012): 
Antimicrobial activity of olive leaf aqueous extract.

Scholars Research Library. Annals of Biological Research, 2012, 3(8):4189-4191 Downloaded from http://scholarsresearchlibrary.com Aytul, K. K., Korel, F., ArserimUçar, D. K., Uysal, I. and Bayraktar, O. (2008): Efficacy of olive leaf extract for enhancing quality of beef cubes, the international congress of meat science and technology,51,augest 10-15, Cape town, South Africa.

Aytul, K. K. (2010): Antimicrobial and antioxidant activities of olive leaf extract and its food applications. Turkey, Ms. Thesis, Graduate School of Engineering and Sciences of Izmir Institute of Technology.

Baker, I. A. (2014): Investigation on Antimicrobial and Antioxidant Effect of Olive Leaf Extract in Karadi Sheep Meat during Storage. Journal of Biology, Agriculture and Healthcare 4(9):46-49.

Devatkal, S. K., Thorat, P. R., Manjunatha, M. and Anurag, R. K. (2012): Comparative antioxidant effect of aqueous extracts of curry leaves, fenugreek leaves and butylated hydroxytoluene in raw chicken patties. Journal of Food Science and Technology 49(6): 781-785.

Erdohan, Z. O. Cam, B. and Turhan, K. N. (2011): Olive leaf extract and usage for development of antimicrobial food packaging. Science against microbial pathogens: communicating current research and technological advances

A. Méndez-Vilas (Ed.)

CFORMATEX 2011

FDA (2001): BAM,

Staphylococcus aureus, Reginald W. B. and Gayle A. L. (Eds). Bacteriological Analytical Manual, 8th Edition, Revision A, 1998. Chapte12.Downloadedfromhtt p://www.fda.gov/Food/FoodScience Research/LaboratoryMethods/ucm2 006949.htm

FDA (2007): BAM, Salmonella. Wallace, H. A. and Thomas $\mathrm{H}$. (Eds). Bacteriological Analytical Manual, 8th Edition, Revision A, 1998.

Chapte5.Downloadedfromhttp://ww w.fda.gov/Food/FoodScienceResear ch/LaboratoryMethods/ucm070149. $\mathrm{htm}$

Fisher, K., and Phillips, C. (2008.): Potential antimicrobial uses of essential oils in food: Is citrus the answer? Trends in Food Science and Technology, 19(2), 156-164.

Gök, V. and Bor, Y. (2012): Effect of olive leaf, blueberry and Zizyphus jujuba extracts on the quality and shelf life of meatball during storage. Journal of Food Agriculture and Environment 10 (2): 190-195.

Hansen, M. N. D., Andrew, V.N.D., Dip, H., Dip, N. and Dip, I. (2013): Olive Leaf Extract Potent Antibacterial, Antiviral and Antifungal Agent. Downloaded fromhttp://www. Naturamedics.com Hayes, J. E., Stepanyan, V., Allen, P., O'Grady, M. N. and Kerry, J. 
P. (2011): Evaluation of the effects of selected plant-derived nutraceuticals on the qualityand shelf-life stability of raw and cooked pork sausages. Journal of Food Science and Technology 44(1): 164-172.

Hayes, J. E., Stepanyan, V., Allen, P., O'Grady, M. N., O'Brien, N. M. and Kerry, J. P. (2009): The effect of lutein, sesamol, ellagic acid and olive leaf extract on lipid oxidation and oxymyoglobin oxidation in bovine and porcine meat. Journal of Meat Science 83(2):201-208.

Healthy Christian Living (2014): HCL Brand Olive Leaf Extract Capsules. Downloaded from http://healthychristianliving.com

Korukluoglu, M., Sahan, Y., Yigit, A., Ozer, E. T. and Gucer, S. (2010): Antibacterial activity and chemical constitutions of Olea europaea L. leaf extracts. Journal of Food Processing and Preservation 34(3): 383-396

Kuete, V., Metunob, R., Ngamenib, B., Tsafack, A. M., Ngandeuc, F., Fotso, G. W., Bezabih, M., Etoa, F. X., Ngadjui, B. T. and Abegaz, B. M. (2007): Antimicrobial Activity of the Methanolic Extracts and Compounds from Treculia obovoidea (Moraceae). Journal of Ethnopharmacology 112(3): 531536.

Lee, O. H. and Lee, B.Y. (2010): Antioxidant and Antimicrobial Activities of Individual and Combined Phenolics in Olea europea Leaf Extract. Journal of Bio-resource Technology 101(10): 3751-3754.

Markin, D., Duek, L. and Berdicevsky, I. (2003): I. In vitro Antimicrobial Activity of Olive Leaves. Mycoses 46 (3-4): 132-136. Mathew, A. G., Cissell, R. and Liam thong, S. (2007): Antibiotic resistance in bacteria associated with food animals: a United States perspective of livestock production. Journal of Food borne Pathogens and Disease 4(2):115-133.

Ngwoke, K. G., Odimegwu, D. C. and Esimone, C.O. (2011): Antimicrobial natural products. In: Mendez-Vilas A, (Ed.) Science against microbial pathogens: communicating current research and technology advances. Badajoz, Spain p. 1011- 1026.

Pereira, A. P., Ferreira, C. F. R., Marcelino, F., Valentão, P., Andrade, P. B., Seabra, R., Estevinho, L., Bento, A. and Pereira, J. A. (2007): Phenolic Compounds and Antimicrobial Activity of Olive (Olea europaea L. $C v$. Cobrançosa) Leaves. Molecules, 26(12): 1153-1162

QSOP18 (2005): Standard operating procedure for Recommended Minimum Internal Quality Control in Food Microbiology Testing Laboratories QSO P18, (4.2):1-10.

Ritchason, J. (2000): Olive leaf extract-Potent antimicrobial, antiviral and antifungal agent, Woodland Publishing; Australia. 
Saeed, A. Hayek, R. G. and Salam, A. I. (2013): Antimicrobial Natural Products. Microbial pathogens and strategies for combating them. Méndez-Vilas, A. (Ed.) science, technology and education Microbiology Book series- No.\#4, 2013 ed..

SAS Institute (1988): SAS User's Guide. SAS Institue Inc., Cary, NC. Sofos, J. N. 2008. Challenges to meat safety in the $21 \mathrm{st}$ century. Journal of Meat Science 78(1-2):313.

Srinivasan, D., Nathan, S., Suresh, T. and Perumalsamy, P. L. (2001): Antimicrobial activity of certain Indian medicinal plants used in folkloric medicine. Journal of Ethnopharmacology 74:217-220.

Sudjana, A. N., D'Oraizo, C., Rayan, V., Rasool, N., Ng, J., Islam, N., Riley, T. V. and Hammer, K. A. (2009): Antimicrobial activity of commercial Olea europaea (olive) leaf extract. International Journal of Antimicrobial Agents 33(5): 461463

Szczesniak, A. S. (1987): Correlation sensory with instrumental texture measurements: An overview of recent developments. Journal of Texture Studies 18 (1): 1-15.

Tabera, J., Guinda, A., RuizRodriguez, A., Senorans, J. F., Ibanez, E., Albi, T. and Reglero, G. (2004): Countercurrent supercritical fluid extraction and fractionation of high-added-value compounds from a hexane extract of olive leaves. Journal of Agriculture and Food Chemistry 28; 52(15):4774-4779.

Tahir, L. and Khan, N. (2012): Antibacterial potential of crude leaf, fruit and flower extracts of Tagetes Minuta L. Journal of Public Health and Biological Sciences 3:74-78.

Tassou, C. C. and Nychas, G. J. E. (1994): Inhibition of Staphylococcus aureus by olive phenolics in broth and in a model food system. Journal of Food Protection 57:120-124.

Tassou, C.C. (1995): Inhibition of Salmonella entertidis by oleuropein in broth and in a model food system. Letters in Applied Microbiology 20(2):120-124.

Tayel, A. A. and El-Tras, W. F. (2012): Plant Extracts as potent Biopreservatives for Salmonella Typhimurium Control and Quality Enhancement in Ground Beef. Journal of Food Safety 32 (1), 115121.

Tayel, A. A., El-Tras W. F., Moussa S. H. and El-Sabbagh S. M. (2012): Surface Decontamination and Quality Enhancement in Meat Steaks Using Plant Extracts as Natural Biopreservatives. Journal of Food borne Pathogens and Disease 9(8):755-761.

Tranter, H. S., Tassou, S. C. and Nychas, G. J. (1993): The effect of the olive phenolic compound, oleuropein, on growth and enterotoxin B production by Staphylococcus aureus. Journal of Applied Bacteriology 74(3):253259. 


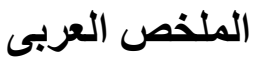

فاعلية مستخلص أوراق الزيتون على إزالة التلوث بميكروب السالمونيلا تيفيميوريم و المكور العنقودي الذهبي في الزفي اللحم المفري.

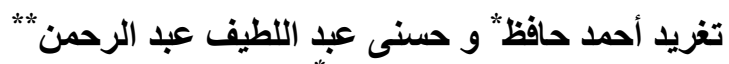

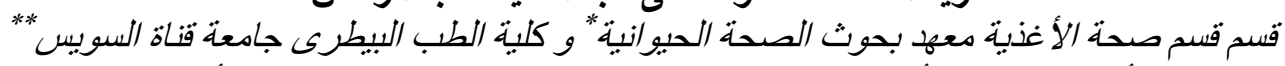

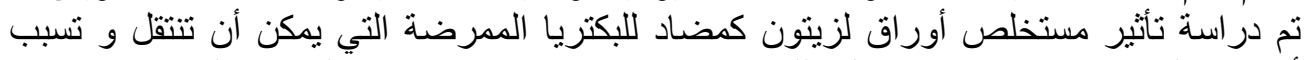

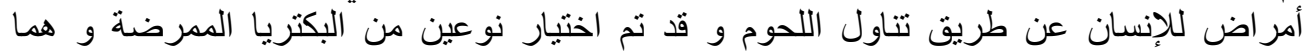

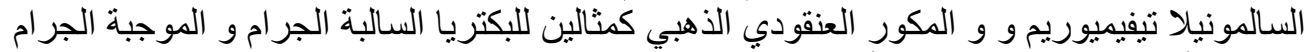

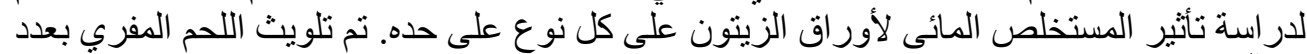

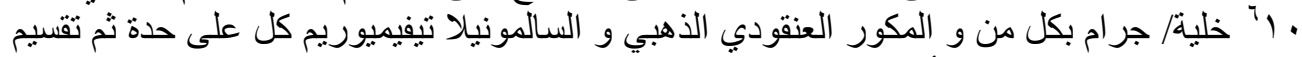

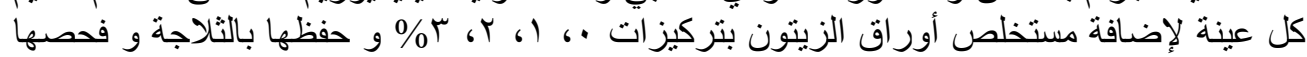

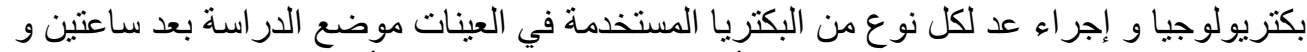

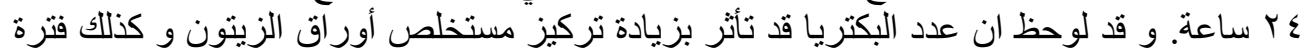

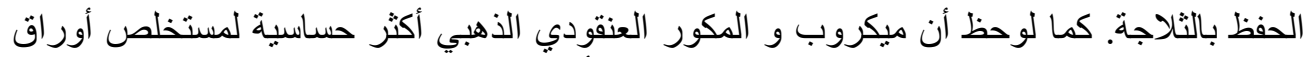

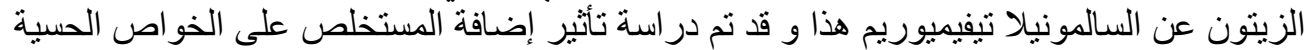

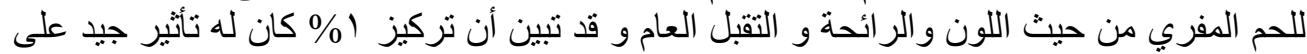
المو اصفات الحسية للحم المفري 